\title{
The first formulation of image-based stereotactic principles: the forgotten work of Gaston Contremoulins
}

\author{
Cole A. Giller, MD, PhD, MBA, ${ }^{1}$ Patrick Mornet, MD, AlHP, ${ }^{2}$ and \\ Jean-François Moreau, MD, AIHP, FACR ${ }^{3}$
}

\begin{abstract}
${ }^{1}$ Neurosurgery Department, Augusta University, Augusta, Georgia; 'La Rochelle, France; and ${ }^{3}$ Université \& Faculté de Médecine
\end{abstract} Paris Descartes, PRES Sorbonne-Paris Cité, Paris, France

\begin{abstract}
Although image-based human stereotaxis began with Spiegel and Wycis in 1947, the major principles of radiographic stereotaxis were formulated 50 years earlier by the French scientific photographer Gaston Contremoulins. In 1897, frustrated by the high morbidity of bullet extraction from the brain, the Parisian surgeon Charles Rémy asked Contremoulins to devise a method for bullet localization using the then new technology of $x$-rays. In doing so, Contremoulins conceived of many of the modern principles of stereotaxis, including the use of a reference frame, radiopaque fiducials for registration, images to locate the target in relation to the frame, phantom devices to locate the target in relation to the fiducial marks, and the use of an adjustable pointer to guide the surgical approach.

Contremoulins' ideas did not emerge from science or medicine, but instead were inspired by his training in the fine arts. Had he been a physician instead of an artist, he might have never discovered his extraordinary methods.

Contremoulins' "compass" and its variants enjoyed great success during World War I, but were abandoned by 1920 for simpler methods. Although Contremoulins was one of the most eminent radiographers in France, he was not a physician, and his personality was uncompromising. By 1940, both he and his methods were forgotten. It was not until 1988 that he was rediscovered by Moreau while reviewing the history of French radiology, and chronicled by Mornet in his extensive biography.

The authors examine Contremoulins' stereotactic methods in historical context, describe the details of his devices, relate his discoveries to his training in the fine arts, and discuss how his prescient formulation of stereotaxis was forgotten for more than half a century.
\end{abstract}

https://thejns.org/doi/abs/10.3171/2016.10.JNS161966

KEY WORDS stereotaxis; history of medicine; stereotactic surgery; gunshot wounds; art and science; radiology

$\mathrm{I}$ $\mathrm{T}$ is widely accepted that the first image-based human stereotactic procedure was performed in 1947 by Spiegel and Wycis, ${ }^{92}$ based on concepts pioneered by Horsley and Clarke. ${ }^{45}$ It is less well known that the first device incorporating stereotactic principles with $\mathrm{x}$-rays was invented 50 years earlier by the French photographer Gaston Contremoulins and successfully used in humans to localize and extract intracranial bullets early in $1897 . .^{67,68,83} \mathrm{His}$ methods, developed only 16 months following the discovery of $x$-rays ${ }^{86}$ included most of the elements of modern stereotaxy and, remarkably, were inspired by techniques used by artists for sculpture and drawing.

Although Contremoulins became one of the most eminent radiographers in France, his methods were forgotten by 1940 , and he himself slipped into obscurity. ${ }^{67,74}$ Many historical accounts omit him completely, ${ }^{27,32,46,77,89,93,97,98}$ and he is only rarely mentioned in the English language., ${ }^{2,4,37}$ In 1988 his work was accidentally rediscovered, ${ }^{65,67}$ but even several years later he was only briefly mentioned in the historical literature. ${ }^{63,72}$

We describe the stereotactic method of Contremoulins, its origins from techniques of art, and its similarity to modern stereotaxis. We discuss how stereotactic ideas invented late in the 19th century to locate foreign objects became forgotten before the reinvention of stereotaxis 50 years later.

\section{Gaston Contremoulins: Early Years and Training}

Contremoulins was born in Rouen, France, in 1869. His father was a respected locksmith, and his grandfather was a skilled mechanic who serviced some of the first locomo- 
tives. The family tradition of precision mechanical work had a profound influence, enabling him to later build the radiological devices for which he became famous (Fig. 1). ${ }^{67}$

Contremoulins was neither a physician nor a physicist, but instead was a gifted artist trained at the School of Fine Arts (École des Beaux-Arts) in Rouen, where he studied drawing and sculpture for 3 years. The school exposed him to viewpoints and provided training that would later inspire his scientific activities: a mildly rebellious attitude toward conventional art, ${ }^{23}$ an appreciation of the new field of photography, ${ }^{75}$ and a set of technical artistic skills. After leaving the Ecole, his attempt to earn a living as an artist in Paris was so unsuccessful that he was forced to use the heat from hallway lanterns to cook his meals. ${ }^{67}$ His artistic talents would have to wait until he could find other employment.

\section{Attachment to Étienne-Jules Marey}

At that time, Étienne-Jules Marey was one of the most celebrated physicians in Paris. ${ }^{91,95}$ Like Contremoulins, he valued precision mechanical work, inventing a sphygmograph to record the pulse waveform and a "photographic gun" that could acquire 12 images each second. Inspired by the work of Muybridge, Marey studied the motion of animals and humans, including a famous recording of a cat landing on its feet. ${ }^{91} \mathrm{He}$ was a member of the prestigious Académie de Médecine, and became president of both the Académie de Sciences and the Institut de France in 1895.

Driven by his interest in photography and his need for employment, Contremoulins became a technician in the microphotography laboratory of the Paris Faculty of Medicine under the direction of Mathias Duval in 1890. Duval's secondary appointment as a professor of anatomy at the École Nationale des Beaux-Arts of Paris ${ }^{26,31}$ likely added to the profound influence that the arts would have upon Contremoulins.

Contremoulins' talents were quickly recognized. He was chosen by Marey in 1894 to work as his préparateur, participating in Marey's studies of locomotion and developing some of the technology that made the studies possible. ${ }^{56,65,67,80,81}$ Marey was also a painter and sculptor, believing that "science and art meet in the search for truth." 67 His movies of flying birds were known both for their value to the field of aviation and as works of art, and the painter Marcel Duchamp was inspired to create his famous "Nude Descending a Staircase, No. 2" by Marey's movies of locomotion. ${ }^{12,48}$ Despite a 40 -year difference in age, Contremoulins and Marey seemed to be kindred spirits, sharing an artistic appreciation of nature for years that would later become pivotal. Contremoulins would draw upon the techniques of fine arts to develop his stereotactic methods, and Marey would repeatedly use his considerable influence to support the career of his younger colleague. ${ }^{67}$

\section{The Advent of Radiography}

Three years after Marey and Contremoulins began their collaboration, Wilhelm Roentgen announced his discovery of x-rays, ${ }^{86}$ and soon after that "a little army of workers [was] busy in all parts of the world, investigating

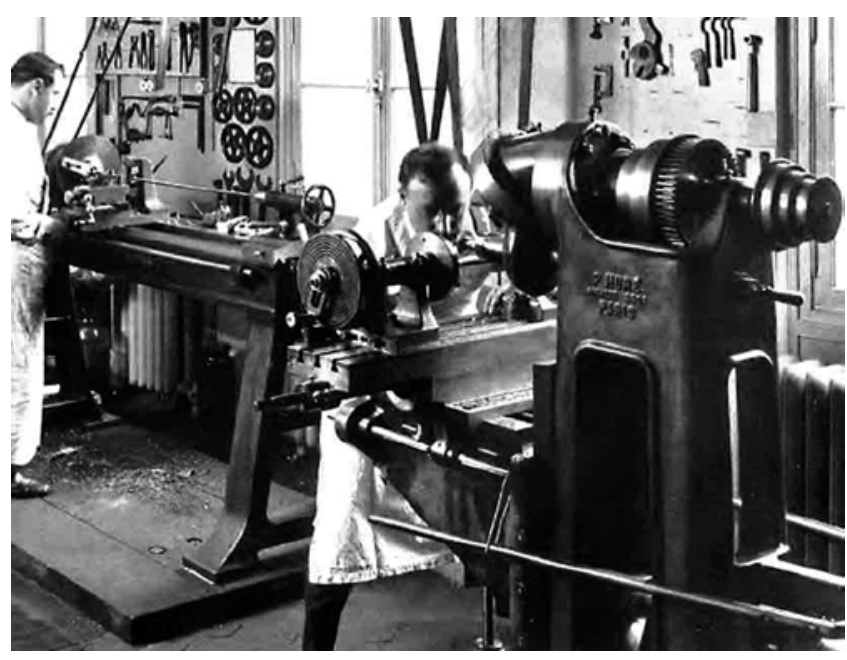

FIG. 1. Contremoulins in his workshop, in which his devices were fabricated. Contremoulins is in the foreground ${ }^{67}$ Copyright owned by Patrick Mornet (coauthor).

the nature and properties of the X-rays." ${ }^{99}$ At first, X-ray devices were freely available. Customers in stores could view images of their own bones for a small fee, and x-rays were used in parlors to stage glowing occult séances. ${ }^{48,67}$ Without the restrictions that would come later, Contremoulins was free to explore this new technology that piqued his interest as a photographer. When a laboratory for the study of the effects of x-rays was established under direction of the surgeon/histologist Charles Rémy in Paris, Contremoulins quickly became its préparateur. ${ }^{67} \mathrm{He}$ and Rémy began a long and fruitful collaboration, exploring x-ray studies of organs, the use of angiography in cadavers, and the localization of foreign objects and contributing many innovations in radiographic technology ${ }^{79-81,83}$

\section{The Treatment of Gunshot Wounds to the Head in the 19th Century}

Treatment of gunshot wounds in the early 19th century included poultices of bread and milk, with surgery deferred unless needed for hemostasis..$^{30}$ But by the mid1800s, Gross listed the extraction of bullets as one of the 5 principles for the treatment of gunshot wounds, and observed that "the best probe...is the finger." ${ }^{38}$ In 1873, Erichsen stated that bullets "cannot be allowed to remain lodged in the body with impunity" and that military surgeons agreed that "Bullets should always be extracted if they can be found." ${ }^{33}$ However, he advised against deep exploration of gunshot wounds to the head. By 1893, Keen advocated aggressive bullet extraction from the head in An American Textbook of Surgery. ${ }^{47}$ For deep-seated fragments, he recommended passing a probe through the brain along the bullet track to the opposite side of the skull, where a trephination was performed. Silk strands and catheters were passed between the wounds to guide passage of a forceps through the brain to grab the bullet.

A preoccupation with bullet extraction is also evident in historical accounts. Physicians caring for Abraham Lincoln after his fatal gunshot wound explored his brain with their fingers to search for the bullet and evacuate any 

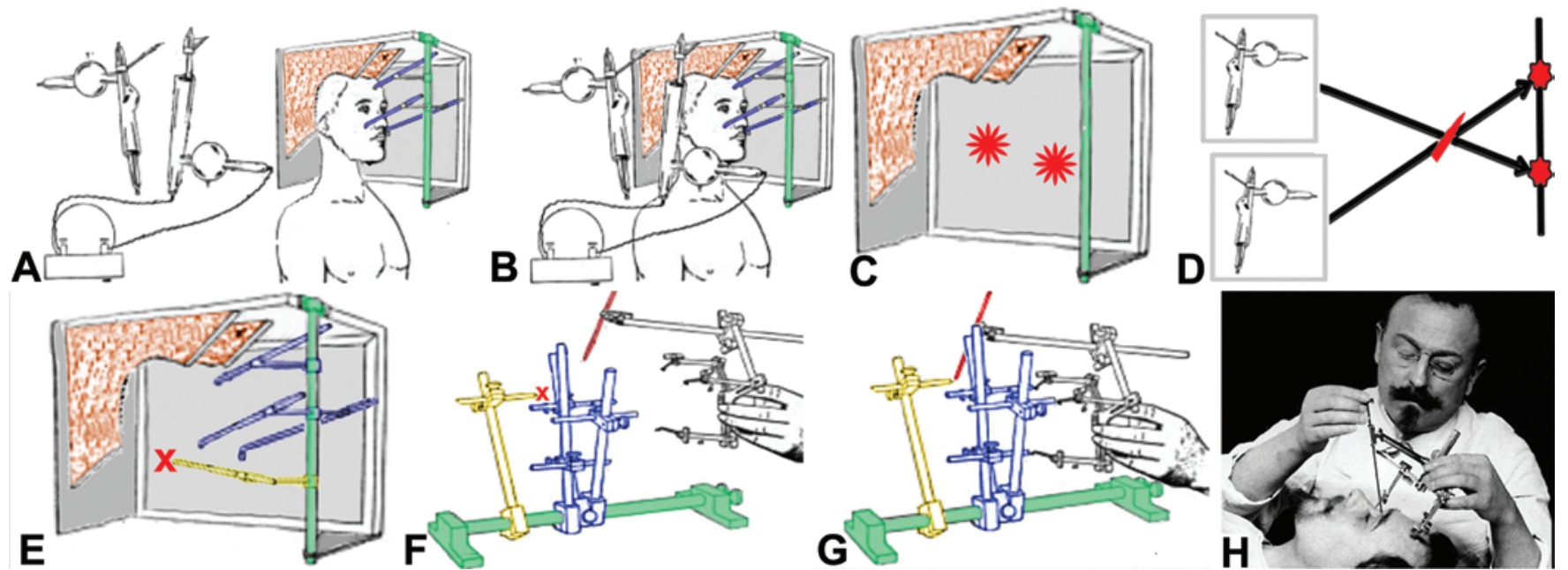

FIG. 2. Diagrams showing the steps of Contremoulins' method for finding intracranial foreign objects (Panels $A$ to $G$ ) and photograph of Contremoulins using his device $(\mathrm{H})$. A: Wooden slats $(r e d)$ contoured to the patient's head are used to anchor the frame to the patient, along with plaster of Paris (not shown). Compare with Fig. 6 . A radiographic plate (gray) is attached to the wall of the frame. Three metal arms (blue) are attached to a bar of the frame (green) and adjusted to touch 3 fiducial marks on the face. Two Crookes tubes (cylindrical devices at left) are attached to a Ruhmkorff coil. B: The Crookes tubes are mounted on the frame so that their beams traverse the head at different angles. C: The 2 beams create 2 images of the intracranial bullet on the plate. D: Wires are suspended between each image and its corresponding Crookes tube. The intersection of the 2 wires marks the location of the bullet. E: The frame is removed from the head, and a fourth arm is attached so that its tip coincides with the bullet site. F: The bar of the frame and the attached arms are removed (the compas repere) and a second device (the compass schema) with 4 arms (held by hand) is adjusted so that its arms touch the tips of the original arms. G: The fourth arm of the handheld compass (red) can swivel in all directions and is adjusted so that its tip marks the location of the bullet and so that its trajectory represents an optimal surgical approach. H: Holding the compass so that its 3 arms touch the fiducial marks, the surgeon is led to the bullet site by the fourth arm (Contremoulins shown in figure). Compare with Fig. 5. Panels A-G drawn by the author (C.A.G.) after Rémy C, Contremoulins G: Le chercheur de projectiles. L'Illustration 55:423, 1897. ${ }^{82}$ Copyright L'Illustration (www.lillustration. com). Published with permission. Panel H copyright owned by Patrick Mornet (coauthor). Published with permission.

intracranial hematomas. ${ }^{6}$ The gunshot wound of President James Garfield in 1881 was explored by many fingers and probes to retrieve the bullet, resulting in perforation of his liver. Locating that bullet even attracted national interest, with headlines demanding "Where is the Bullet?" 48,101 To a modern observer, the insistence on bullet extraction seems almost obsessive.

Surgeons therefore seized upon the new x-ray technology to aid their search for bullet fragments.9,82,98,99 But problems of parallax and depth ${ }^{28,82}$ made matters difficult, and it became clear that geometrical methods would be required. The first such method used $2 \mathrm{x}$-ray images taken from different positions to deduce the depth of the bullet beneath the skin,,$^{10}$ and hundreds of localization methods were eagerly advanced over the next 20 years. ${ }^{5,8,14,70,78}$ Rémy and Contremoulins thus began their collaboration just as the medical world became obsessed with methods for bullet localization and just as the need for mathematical algorithms became appreciated. With his expertise in the geometry of art and of precision machining, Contremoulins was perfectly poised to make important contributions to the new field of radiology.

\section{Contremoulins' Compass}

In 1896, Rémy encountered a 20-year-old man who had been blinded by a gunshot wound to the head 7 years earlier. ${ }^{67}$ The patient had heard that extraction of the bullet within his head was possible with the use of x-rays and believed the prevailing opinion that extraction might cure his blindness. Convinced by the patient's desperation, Rémy agreed to operate, and he asked Contremoulins to obtain lateral and anteroposterior radiographs for surgical guidance. During surgery, Rémy aggressively explored the subfrontal space with his finger for an hour but was unable to find the bullet. ${ }^{67,83}$ The patient recovered from the surgery but continued his fervent requests for extraction.

\section{Description of Device and Method}

Contremoulins realized that ordinary x-ray images were not sufficient to locate intracranial objects at surgery and that the geometrical information contained in the $\mathrm{x}$ ray images had to be transferred to a localization device. Guided by methods used by artists to transfer shapes between media, he rigidly attached a rectangular wooden frame to the head by means of a form-fitting template and a layer of plaster. The frame supplied a reference to which all other components of the device were attached (Fig. 2). Two Crookes tubes mounted on one side of the frame were aimed at the head from different angles, producing $2 \mathrm{im}$ ages of the bullet on a radiographic plate mounted on the other side. Three small metallic disks were then attached to the patient's face, one on the forehead, and the other 2 on the malar eminences. The sites of the disks were tattooed on the skin for future reference. Contremoulins then attached 3 cylindrical arms to the frame so that the tip of each arm touched one of the 3 markers (Fig. 2). 
The frame was then removed from the head without changing the position of its attached components. A metal wire was passed between each image of the bullet and the center of the corresponding Crookes tube, so that the intersection of the 2 wires marked the position of the bullet. A fourth arm was then attached to the frame and adjusted to touch this point of intersection to mark the bullet's position. Contremoulins called the collection of the 4 arms together with the bar to which they were attached the compas-repère (reference compass), and used it to preserve the relationship between the fiducial marks and the location of the bullet. He reported that it had been inspired by the compas des praticiens, a device used by artists to copy sculpture. ${ }^{83}$

A second compass (the compas-schéma, or planning compass) was constructed to copy the geometrical information contained in the compas-repère for use during surgery. It consisted of a handheld platform attached to 4 adjustable rods (Fig. 2). Three of the arms were adjusted to touch the tips of the $3 \mathrm{arms}$ of the compas-repère that had marked the fiducial points. The fourth rod was adjustable in all directions and equipped with a blunt probe running through its lumen. The rod and probe were adjusted so that the probe touched the tip of arm that marked the location of the bullet, and then adjusted to anticipate the optimal surgical trajectory (Fig. 2).

At surgery, the planning compass was held to the head of the patient so that its 3 fiducial rods touched the fiducial tattoos on the patient's face. The fourth rod thus pointed at the location of the bullet, which could be found by advancing the probe through the lumen of the rod.

After testing their device with a cadaver skull, ${ }^{79}$ Contremoulins and Rémy extracted the bullet from the young patient described above with complete confidence and perfect success.

\section{Later Versions}

The first version, described in March of $1897,{ }^{83}$ did not use intersecting wires to mark the location of the bullet. Instead, Contremoulins borrowed techniques for constructing topographic maps to reconstruct the location of the bullet from precise drawings of the x-ray images and the fiducial disks. He omitted the details, however, writing, "Tout ce que le chirurgien doit demander à cette étude, c'est la connaissance bien précise de la position du projectile par rapport aux points de repère extérieurs du crane" (All the surgeon needs to know from this study is the precise location of the projectile with respect to the external landmarks of the skull) ${ }^{83}$ This omission may have prompted the later criticism that his method was prohibitively complex.

The next version was described in November of $1897 .{ }^{79}$ Because of the difficulty of precisely locating the x-ray source within each Crookes tube, Contremoulins devised an indirect method to place the wires marking the x-ray beams. For each tube, an image was obtained of a metal plate penetrated by 4 small holes. Connecting 4 wires from the images of the holes through the holes themselves identified the source because of the divergence of the x-ray beam.

Another version relied solely on fluoroscopy rather

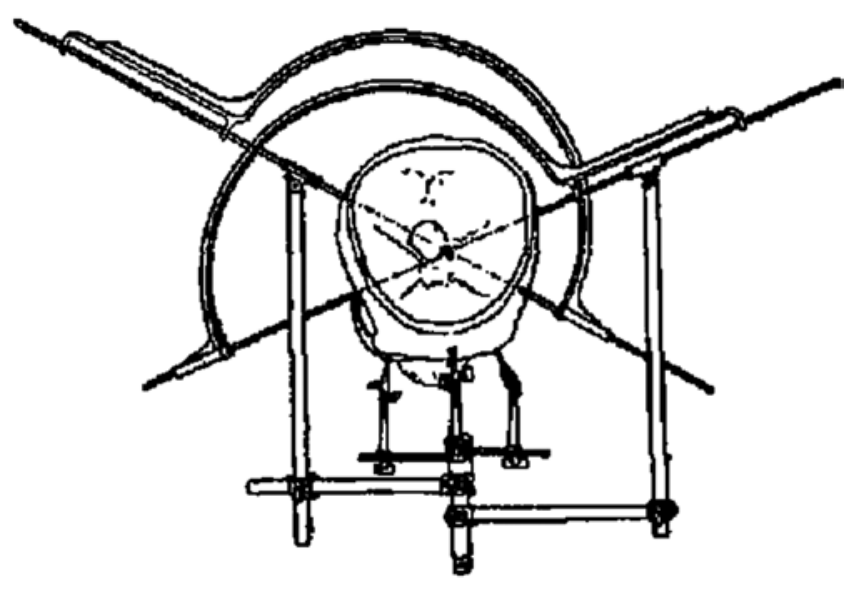

FIG. 3. Schematic of Contremoulins' compass device used with fluoroscopy. See text for details. From Contremoulins G: Méthode exacte de localisation et de recherche des corps étrangers dans l'organisme par la radioscopie. Bulletin de l'Académie Nationale de Médecine 78:423-426, 1904. Public domain.

than photographic plates (Fig. 3). ${ }^{20}$ By moving the fluoroscope to superimpose the target with a marker placed on the scalp, a straight line through the target could be identified. A second line was identified with a different marker, intersecting the first line at the target. A compass was then applied to the patient as usual, but equipped with a large metal half-circle for each line, positioned so that the diameter of the circle coincided with the line. With the use of probes attached at the ends of the half-circles that pointed inward along the line, the target could be located with a phantom compass and then located in the patient with an operating compass (Fig. 3).

Subsequent improvements included a stronger planning compass, better suited for the operating room (the compas d'opération), ${ }^{36}$ and the use of more stable pedestals that resembled film holders for stereotactic procedures invented almost 50 years later (Fig. 4). ${ }^{19,87}$ In the 1906 version, specific markers determined the position of the x-ray sources to simplify the attachment of the intersecting wires, and the 1916 version used a single Crookes tube that slid between 2 positions (Fig. 4).

\section{Similarity to Modern Stereotaxis}

Contremoulins' method, devised only 16 months following the discovery of x-rays, articulated many of the principles of modern stereotaxis. He defined geometrical space with the use of a frame and used a phantom device for localization as did the early frames of Talairach, Riechert, and the Brown-Roberts-Wells (BRW) system. ${ }^{27,40,85} \mathrm{He}$ initially used plaster to anchor the head, as did Spiegel and Wycis in their first efforts. ${ }^{92}$ His use of the radiographic relationship between fiducial marks and the target to guide the surgeon's probe is a method that continues to be essential for stereotactic procedures today.

\section{Influence of the Fine Arts}

Contremoulins was inspired by 2 techniques that he had likely learned at the École des Beaux-Arts. ${ }^{83}$ The first was the use of a device to copy sculpture known in France 


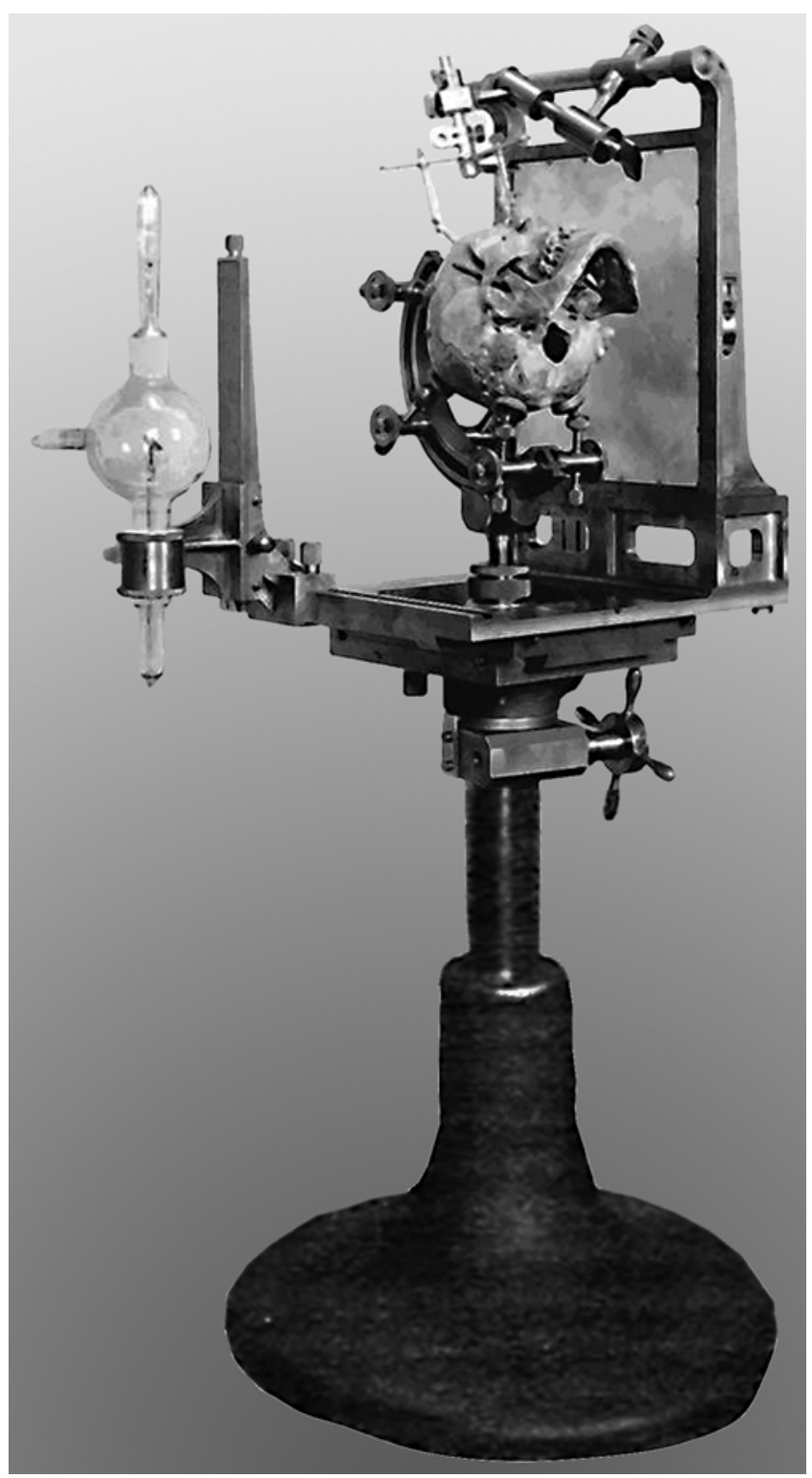

FIG. 4. Photograph of Contremoulins' compass device from 1916. A single Crookes tube is moved between 2 positions, mounted to facilitate attaching a wire to the origin of the $x$-ray beam. The device is more stable than the original versions. Compare with the more portable Hirtz compass shown in Fig. 8. From Routier AE: Nouvel appareil de M. Contremoulins pour la localisation radiologique des corps étrangers de la tête. Bulletin de L'Académie de Médecine 80:561-570, 1916. Public domain.

as a compas des praticiens (a praticien was a professional carver assisting the sculptor). It was known in England as a "pointing tool" 73,102 and is still available today (Fig. 5). It consisted of 3 rods rigidly attached to the object to be copied, together with a pointer adjusted to touch a chosen site on the sculpture. The apparatus was detached from the sculpture and reattached to a new block of marble. The pointer indicated where the marble had to be chiseled away to replicate the chosen site, and the process was repeated until the copy was complete.

The second inspiration was the method of Lausse-

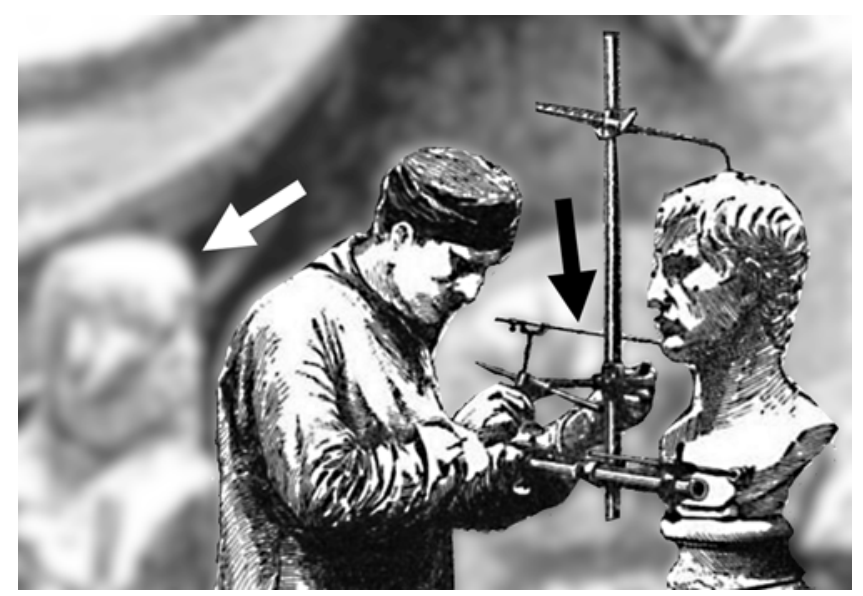

FIG. 5. Engraving showing artist adjusting a pointing tool to copy a bust. After the pointer (black arrow) is moved to touch a chosen site on the sculpture, the device is attached to a block of marble (white arrow) and the carving is guided by the pointer. Compare with Fig. $2 \mathrm{H}$. From Partridge WO: Technique of Sculpture. Boston: Ginn and Company, 1895. Public domain.

dat, ${ }^{54,55,83}$ used to create topographical maps from photographs, similar to the projective drawing Contremoulins had learned at the École. ${ }^{35}$ Substituting the x-ray source for the camera lens and the x-ray plate for the projective plane, the intersection of $2 \mathrm{x}$-rays through the bullet could be determined. As mentioned, he soon replaced the drawings with intersecting wires. ${ }^{62,79}$

Contremoulins' inspiration to use a rectangular frame may have come from older methods of sculpture replication, in which one frame was placed over the object to be copied and another placed over a block of stone. ${ }^{53}$ Measurements between the frames and the objects under them were used to guide the carving (Fig. 6).

\section{Reaction to the Compass Method}

Fueled by the obsession with bullet extraction, the difficulty of localization, and the endorsement of Marey, Contremoulins' compass drew immediate acclaim. Marey's presentation of the work to the Académie des Sciences and the Académie de Médecine in 1897 was met with applause, ${ }^{82}$ and Marey himself described Contremoulins' method as a revolution in surgical therapy ("une véritable révolution dans la thérapeutique chirurgicale des projectiles intracrâniens"). ${ }^{62}$ Following Marey's public plea for funding, a donation was made of the required 2500 francs even before the efficacy of the device had been proven. ${ }^{61,82,83}$

The method was used and praised by other surgeons. The chairman of surgery at the Necker Hospital, JeanFrancois-Auguste Le Dentu, had long taught that the dangers of bullet extraction from the brain were prohibitive. But after witnessing Contremoulins demonstrate his method on a cadaver, he used the method himself to perform a successful extraction. ${ }^{61,62,67}$ Tuffier reported the successful extraction of intracranial bullets in 2 patients, stating that 31 such extractions had been performed in the region of Paris by $1901 . .^{96}$ Extractions from the brain, spine, lung, mediastinum, and chest were reported, and physicians 

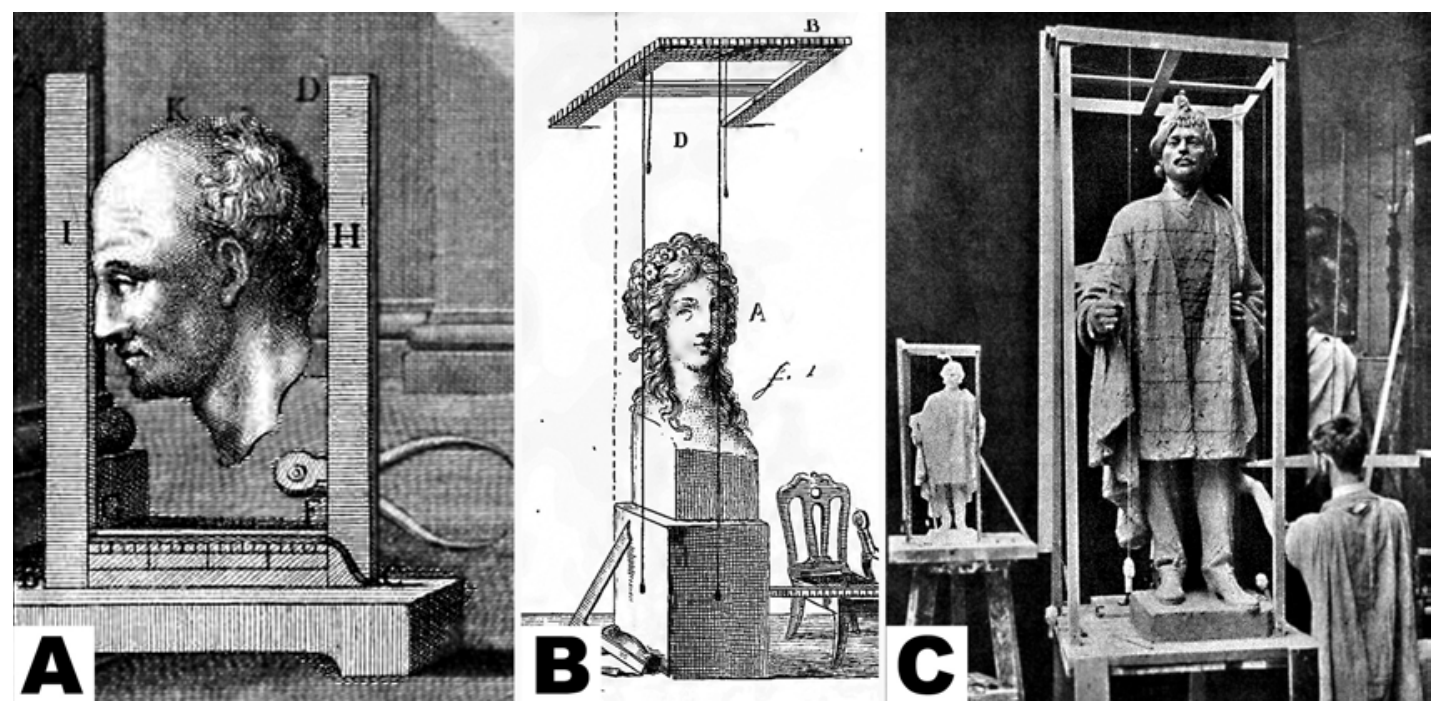

FIG. 6. A: Engraving from the 15th century showing the use of a rectangular frame to replicate a bust. From Alberti LB: Della architettura della pittura e della statua. Bologna: Nell' Instituto delle Sciente, Bologna, 1782, Plate 69. Public domain. B: Engraving from the early 19th century showing the use of plumb bobs attached to a frame to replicate sculpture. From Carradori F: Istruzione elementare per gli studiosi della scultura. Pisa: Tipografia della Società Letteraria, 1802, Plate 10. Public domain. C: The use of rectangular frames to replicate sculpture circa 1900. From Lanteri E: Modelling: A Guide for Teachers and Students. Volume III. London: Chapman and Hall, 1911. Public domain. Compare with Fig. 2A.

commented that the method was consistently precise. ${ }^{49,50,}$ $57,58,84,96$ Contremoulins himself extracted fragments from the brain in 77 patients by $1904,,^{20,52}$ and in 149 of 155 patients by $1906 .{ }^{67}$ A review in 1898 described his method as "vraiment élégante," praising its ability to locate small slivers of bone. ${ }^{36}$

Contremoulins' compass attracted international attention. It was used by the Russian army during their war with Japan in 1904-1905. The sultan of Turkey made requests for the device, but it was never delivered because of the construction delays. ${ }^{67}$

The method also received public acclaim. An engraving of Contremoulins using his compass with Rémy at his side filled the cover of the November 1897 edition of L'Illustration, a popular magazine known for its photographs and drawings (Fig. 7). ${ }^{82}$ The article described the compass, concluding that Rémy and Contremoulins deserved the highest recognition from the Académie de Médecine. In the United States, Scientific American published the same article with minor revisions the following month. ${ }^{88}$ In the same year, Rémy and Contremoulins won the prestigious Monthyon Prize (a precursor to the Nobel Prize $^{24,25}$ ) for their collected work in radiography.

\section{Contributions of Contremoulins}

Contremoulins became famous for his innovative devices, his methods for localizing foreign bodies, his contributions to the radiology of fractures, his use of x-ray images to guide the manufacture of prostheses and implants, and his radiographic techniques to measure the size of the pelvis. For almost 4 decades, he directed the most sophisticated radiology department in Paris, starting at a time when few hospitals had electric power. His organization of his radiology department was a model for many years. He was one of the first to vocalize the dangers of radia- tion, not only to medical personnel but also to those in adjacent rooms and buildings. Contremoulins published extensively and emphasized the need for specialized training for those employing x-rays. His was a respected, conspicuous, and constant voice in the early development of radiology. ${ }^{16,21,22,66-69}$

\section{The Road to Obscurity: The Compass}

By 1910, hundreds of methods for localization of foreign bodies had been invented. , $8,14,70,78,90,100^{\text {Although }}$ Contremoulins' device was pioneering, many of the other methods were easier to use, more portable, and more suited for the battlefield or for a busy practice. ${ }^{5,11,44,72,97} \mathrm{An}$ example is the Hirtz compass, which anticipated arc-centered stereotaxis by including a rod that slid along an arc

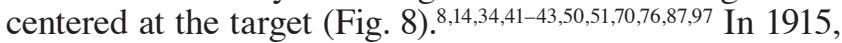
it was "the standard method in most French hospitals," "continued to find enthusiastic support,"14 and its description was given 31 pages in the United States Army X-Ray Manual of 1919.97

The compass method of Contremoulins was thus gradually forgotten, not only because of the simplicity of other methods, but also because the early versions of the method earned a reputation for being difficult due to its use of complex arrays of wires and mysterious diagrams. ${ }^{79,83}$ An exhaustive review in 1918 reported that the method of Contremoulins was "extraordinarily laborious and complicated...used only by its authors," tails of his work while including those of other radiographers. ${ }^{46,70,90}$ Even in modern narrations, his technique is described as "longue et complexe." 72

Surgeons of the time, such as Kirmisson, believed that these assessments were biased and that their criticism was prejudiced. In his remarks to the Académie de Médecine in 1917, he noted that despite excellent results from Con- 


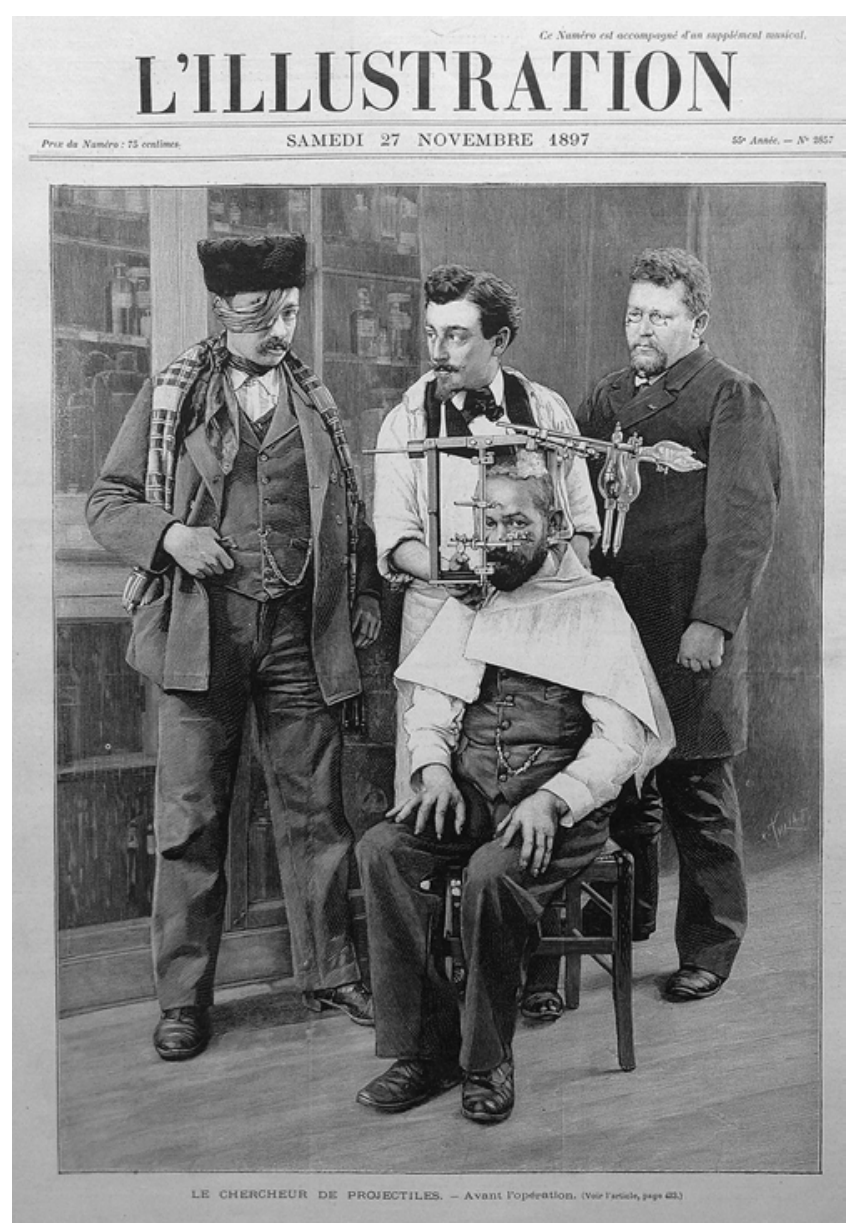

FIG. 7. Cover of L'Illustration from November 1897 showing Contremoulins (center) using his localization device. Charles Rémy is standing to his left. Copyright L'Illustration (www.lillustration.com). Published with permission.

tremoulins' method, and despite its development before that of Hirtz and others, the name of Contremoulins had been wrongly ignored ("le nom de M. Contremoulins est le plus souvent passé sous silence"). ${ }^{49}$

Although the bias against Contremoulins was likely real, all compass methods were abandoned soon after World War I for easier and faster methods. ${ }^{5,11,72,97}$ As one officer said: "This war is not being fought with bird shot and the localization, as a rule, to $0.5 \mathrm{~cm}$ will be entirely satisfactory."'5 After the war, the eminent British radiologist Holland concluded that the localization work had not "brought about any real great advance in the science and art of radiography." ${ }^{\prime 4}$ Furthermore, the perceived need to extract bullet fragments had become less acute. ${ }^{78}$ The compass devices, so useful for difficult cases away from the front, were not even mentioned in published reviews by $1930 .{ }^{14,15,48,64,69,94}$

\section{The Road to Obscurity: Contremoulins}

It is not surprising that the compass of Contremoulins became obsolete. But it is astonishing that after 50 years of innovation and leadership spanning the most formative years of radiology, Contremoulins himself became as ob-
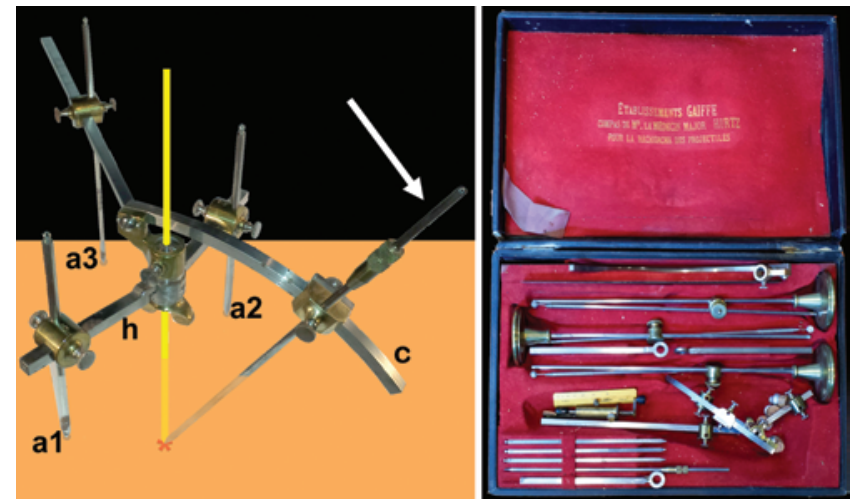

FIG. 8. Left: Schematic illustration of the Hirtz compass. Three vertical arms (a1, a2, and a3) rest on the patient's skin (indicated by tan color) and support a horizontal holder (h). The lengths of the arms are adjusted so that the holder is a specific distance from the targeted object, using calculations derived from radiographs taken from 2 different angles. A metal arc (c) is attached to the holder, designed to be a portion of a circle. Any probe (arrow) placed perpendicular to the arc will encounter the targeted object at the center of the circle defining the arc. Right: Photograph of the Hirtz compass in its case. Compare with Fig. 5. The case and device are from the collection of C. A. Giller.

scure as his device. His name passed from verbal memory even in his own hospital, ${ }^{65-67}$ he was rarely mentioned in the scientific literature after his death in 1950 , and he was omitted from comprehensive historical reviews and museum displays. ${ }^{27,32,48,69,77,89,90,94,98}$ In contrast, the historical record continued to honor many of Contremoulins' contemporaries. For example, Hirtz is memorialized in a painting by the French artist Edmond Suau ("Repérage d'un projectile aux rayons X sur un blessé de guerre," 1920, oil on canvas, Musée de l'Assistance Publique-Hôpitaux de Paris) in which Hirtz is shown at the bedside while his compass is being used.

It was not until 1988 that Contremoulins was rediscovered by the French radiologist and historian, Jean-Francois Moreau, while studying the history of the Necker Hospital. ${ }^{65,67}$ Since then, Contremoulins' work has been included in the monumental review by Pallardy, ${ }^{72}$ chronicled in the extensive biography by Mornet, ${ }^{67}$ and explored in numerous reviews by Moreau and Mornet. ${ }^{65-68}$ The city of Sottevillelès-Rouen honored him by naming a street Rue Gaston Contremoulins.

Contremoulins' obscurity occurred partly because he was not a physician. In the early years of radiology, this was of little concern. Radiographic images were readily available without physician oversight, $48,67,72$ and nonphysicians, such as engineers, were tolerated so that they would be free to develop the required technology. But pressure soon grew to limit the practice of radiology to physicians, because of the dangers of radiation and because a new sense of a social contract between society and medicine ${ }^{59}$ motivated physicians to protect the public from the incompetent radiographers of that time. Financial considerations also played a role, because restrictions granted a monopoly to physicians for radiological services. Physician leaders such as Béclère in France and Kassabian in the United States mounted a "campaign to push out photographers and engineers," ${ }^{48}$ perhaps motivating Béclère to 
dismiss Contremoulins from the military medical corps during World War I.,67 As one historian remarked about the movement to exclude nonphysicians, "It took a little vigorous shaking to root out the riff-raff." 29 The issue was hotly debated for many years until a restrictive law was passed. ${ }^{72}$ Contremoulins was allowed to continue because of his reputation, but the fierce arguments with the powerful physicians opposed to this decision ${ }^{67}$ may have contributed to his omission from the historical record. ${ }^{65-67}$

Personal factors also contributed to Contremoulins' difficulties. On the one hand, his skill was legendary, and his technical staff was loyal. ${ }^{67} \mathrm{He}$ has been described as clever, innovative, and ebullient ("astucieux et inventif"72 and "pétulant" "11). But there are hints of a contentious personality. These include his tense break with Rémy ${ }^{67}$ and his animosity toward powerful physicians, such as Béclère. ${ }^{65,67,71,72}$ His crusade for radiation safety conflicted with the financial interests of other radiologists, ${ }^{65,67,68}$ and provoked an acrimonious controversy in which he countered the "unfounded statements" of his colleagues that radiation posed no danger "since the coffins of my unhappy colleagues have not sufficed to support my views."7 He was also known for excoriating polemics against physicians for their lack of radiographic skills and need for more training. ${ }^{16-18,22,66,67}$ Even at his funeral, an article reported, "avec Contremoulins, rien ne se passait selon les règles normales" (with Contremoulins, nothing occurred according to the normal rules). ${ }^{67}$

\section{Last Years}

At the retirement age of 65 years, Contremoulins left the Necker Hospital to practice under physician supervision in the outskirts of Paris at the Saint-Germain-en-Laye Hospital. He continued to contribute technical innovations, and even assisted in the design of a new hospital. He completed a 2-volume autobiography that was not published because of conditions during World War II. When he became totally blind due to cataracts, he calmly committed suicide in 1950 with a dose of cyanide saved for this purpose. After Le Journal du Dimanche announced his death as that of the premier radiologist of his time, Contremoulins was scarcely mentioned again for almost 40 years. ${ }^{67}$

\section{Discussion}

Driven by the excitement of the early days of radiology and the widespread belief in the necessity of bullet extraction, Contremoulins invented the first radiographic stereotactic device to be used for human surgery. His family legacy of precision machining and support from influential scientists such as Marey were essential to the development of this prescient work, but the most important influence was his training in the fine arts that gave him access to ancient techniques used by sculptors to transfer geometrical information. Had he been a physician instead of an artist, he might have never discovered his extraordinary methods.

Contremoulins' devices were widely used for almost 2 decades, but were forgotten after 1920 with the advent of simpler procedures. Stereotaxis was thus invented twice: once in 1897 to localize bullet fragments, and again in- dependently 50 years later. ${ }^{27,45,92}$ Ironically, Lars Leksell commented that the need for effective methods for bullet extraction during his experience in the Finnish-Russian War provided "part of the emphasis for the development" of his famous Leksell stereotactic frame. ${ }^{60}$

One might argue that Contremoulins' methods were not truly stereotactic because they did not employ an explicit coordinate system. However, the word "stereotaxis" refers to the precise positioning of an object in space, with or without a Cartesian coordinate system. ${ }^{39}$ Horsley and Clarke were the first to use this term when their frame established the basis for modern stereotaxy, although their device relied on anatomical landmarks rather than imaging and was never used in human surgery. Nevertheless, their method was truly stereotactic and yet depended on calculation of distances to various planes rather than on a strict coordinate system. ${ }^{39,45}$ Regardless of the semantics, the methods of Contremoulins clearly articulate stereotactic principles surprisingly early in the history of radiology.

Contremoulins was described in 1921 as "one of the most eminent radiologists in France,"” and his stereotactic devices inspired a radiographic technology for 2 decades. Yet by 1940 his name and ideas were absent from human recollection, and stereotaxis ceased to exist until its methods were reinvented years later. These events are a reminder that history is far from linear, and that the scientific ideas created for the purposes of one culture can disappear, only to arise again to fulfill the needs of another.

\section{Acknowledgments}

J.F.M. is grateful to Marie-Josée Watremez for sharing with him her thoughts and portions of her dissertation on the life of Contremoulins written in 1983 at the School of Radiology at SaintGermain-en-Laye. P.M. is grateful to Ms. Andrée Madou for introducing him to the history of Contremoulins and for sharing related historical materials in her possession.

\section{References}

1. Alberti LB: Della architettura della pittura e della statua. Bologna: Nell' Instituto delle Sciente, Bologna, 1782, Plate 69

2. Apra C, Bourdillon P, Lévêque M: Surgical techniques: when brain bullets met crowdfunding. Nature 530:160, 2016 (Letter)

3. Béclère A: Antoine Béclère (1856-1939); pionnier en endocrinologie, l'un des fondateurs de la virologie et de l'immunologie, fondateur de la radiologie française. Paris: J.B. Baillère, 1973

4. Benabid AL, Chabardes S, Seigneuret E: History of stereotactic surgery in France, in Lozano AM, Gildenberg PL, Tasker RR (eds): Textbook of Stereotactic and Functional Neurosurgery, ed 2. Berlin: Springer, 2009, pp 97-111

5. Blonek F: A universal table for the fluoroscopic localization of foreign bodies. Radiology 38:174-185, 1942

6. Bollet AJ: Civil War Medicine: Challenges and Triumphs. Tucson: Galen Press, 2002

7. Bond AR (ed): The deadly X-ray and the innocent bystander. Sci Am 4:109-112, 1921

8. Bowen DR: Localization of foreign bodies. AJR Am J Roentgenol 5:59-74, 1908

9. Brissaud D, Londe A: Photographie par les rayons de 
Roentgen d'une balle de 7 millimètres dans le cerveau. La Nature Revue des Sciences 24:219-220, 1896

10. Buguet A, Gascard A: Determination of the depth or position of a foreign body in the tissues by means of the X-rays. C R Acad Sci 122:786, 1896

11. Busby AH: A practical method of foreign body localization. Surg Gynecol Obstet 27:413-419, 1918

12. Cabanne P: Dialogues with Marcel Duchamp. London: Da Capo Press, 1971, p 34

13. Carradori F: Istruzione elementare per gli studiosi della scultura. Pisa: Tipografia della Società Letteraria, 1802, Plate 10

14. Case JT: A brief history of the development of foreign body localization by means of the X-rays. AJR Am J Roentgenol 5:113-124, 1918

15. Case JT (ed): Conference of military roentgenologists. AJR Am J Roentgenol 4:355-356, 1917

16. Contremoulins G: Le programme des connaissances techniques du radiographiste. Rev Scientifique 38:650-654, 1921

17. Contremoulins G: Les conditions d'exercice de la radiographie appliquée au diagnostic médical. Revue générale des Sciences 18:1012-1021, 1907

18. Contremoulins G: Les connaissances techniques du radiographiste. Archives d'Electricité Médicale 9:568-569, 1901

19. Contremoulins G: Localisation et extraction des corps étrangers logés dans l'organisme, in Premier Congrès International pour l'Etude de la Radiologie et de l'Ionisation. Paris: Dunod and Pinat, 1906, pp 32-48

20. Contremoulins G: Méthode exacte de localisation et de recherche des corps étrangers dans l'organisme par la radioscopie. Bulletin de l'Académie Nationale de Médecine 78:423-426, 1904

21. Contremoulins G: Méthode générale de métroradiographie, in Premier Congrès International pour l'Etude de la Radiologie et de l'Ionisation. Paris: Dunod and Pinat, 1906, pp 17-20

22. Contremoulins G: Métroradiographie. Archives d'Electricité Médicale 9:641-668, 1901

23. Cousinié F (ed): L'impressionnisme: du plein air au territoire. Rouen: Presses universitaires de Rouen et du Havre, 2013, p 103

24. Crawford ET: The Beginnings of the Nobel Institution. Cambridge, UK: Cambridge University Press, 1984, p 14

25. Crosland M: The French Academy of Sciences as a patron of the medical sciences in the early nineteenth century. Ann Sci 66:247-265, 2009

26. Cuyer E, Duval M: Histoire de l'anatomie plastique, les maîtres, les livres et les écorchés. Paris: Société Française d'éditions d'Art, 1898, iii

27. Dagi TF: History of stereotactic surgery, in Greeblatt $\mathrm{SH}$ (ed): A History of Neurosurgery, in Its Scientific and Professional Contexts. Springfield, IL: AANS, 1997, pp 401-437

28. Davidson JM: The principles and practice of the localization of foreign bodies by x-rays. Br Med J 2818:1-5, 1915

29. Dewing SB: Modern Radiology in Historical Perspective. Springfield: Charles C Thomas, 1962, p 83

30. Dorsey JS: Elements of Surgery, Vol 1. Philadelphia: Edward and Richard Parker, 1818, p 66

31. Duval M: Précis d'anatomie à l'usage des artistes. Paris: A. Quantin, 1883

32. Eisenberg RL: Radiology: An Illustrated History. St. Louis: Mosby Year Book, 1992

33. Erichsen JE: The Science and Art of Surgery. Philadelphia: Henry C. Lea, 1873, pp 196, 478

34. Ferrandis JJ, Segal A: L'essor de la radiologie osseuse pendant la guerre de 1914-1918. Rhumatologie Pratique 266:48-50, 2009
35. Flemer JA: An Elementary Treatise on Phototopographic Methods and Instruments. New York: John Wiley and Sons, 1906

36. Gautier E: Les rayons X et leurs applications. L'Année Scientifique et Industrielle 41:52-73, 1897

37. Giller CA: The arc-quadrant principle of stereotaxis: used, forgotten, rediscovered and inspired by warfare. J Neurosurg 123:A511, 2015 (Abstract)

38. Gross SD: A System of Surgery Vol 1. Philadelphia: Blanchard and Lea, 1859, p 389

39. Grunert P Sr, Keiner D, Oertel J: Remarks upon the term stereotaxy: a linguistic and historical note. Stereotact Funct Neurosurg 93:42-49, 2015

40. Heilbrun MP, Roberts TS, Apuzzo ML, Wells TH Jr, Sabshin JK: Preliminary experience with Brown-RobertsWells (BRW) computerized tomography stereotaxic guidance system. J Neurosurg 59:217-222, 1983

41. Hirtz EJ: L'examen radiologique des blessés et la recherche des projectiles. Archives de Médecine et de Pharmacie Militaires 65:499-521, 1916

42. Hirtz EJ: Localisation et extraction des projectiles intracérébraux. La Presse Médicale 39:307-309, 1916

43. Hirtz EJ: Une méthode précise et chirurgicale pour la localisation et la recherche des corps étrangers. Archives d'Electricité Médicale 23:28-41, 1915

44. Holland CT: An address on war lessons for radiology. BMJ 1:353-355, 1920

45. Horsley V, Clarke RH: The structure and functions of the cerebellum examined by a new method. Brain 31:45-124, 1908

46. Kassabian MK: Röntgen Rays and Electro-therapeutics. Philadelphia: Lippencott, 1907

47. Keen WW, White JW (eds): An American Text-Book of Surgery. Philadelphia: W. B. Saunders, 1893, pp 507-510

48. Kevles BH: Naked to the Bone: Medical Imaging in the Twentieth Century. New York: Basic Books, 1998

49. Kirmisson EF: De l'emploi du compas Contremoulins réglé d'après une localisation radioscopique utilisant un rayon normal vertical. Bulletin l'Académie de Médecine 77:522 526, 1917

50. Kirmisson EF: Extraction d'un éclat d'obus situé dans le médiastin antérieur en contact avec la veine cave supérieure. Bulletin l'Académie de Médecine 77:296-298, 1917

51. Kohn R: L'activité scientifique des médecins juifs en France depuis 1789, in Freudenthal G, Kottek S (eds): Mélanges d'histoire de la médecine hébraïque. Leiden: Brill, 2003

52. Lancet: Paris (from our own correspondent). Lancet 163(4215): 1691,1904

53. Lanteri E: Modelling: A Guide for Teachers and Students. Volume III. London: Chapman and Hall, 1911

54. Laussedat A: La Métrophotographie. Paris: GauthierVillars, 1899

55. Laussedat A: Leçons sur l'art de lever les plans. Paris: Mallet-Bachelier, 1861

56. Lefebvre T, Malthête J, Mannoni L: Lettres d'ÉtienneJules Marey à Georges Demenÿ, 1880-1894. Paris: Éditions de la Maison des Sciences de l'Homme \& Association Française de Recherches sur l'Histoire du Cinéma, 1999

57. Loison M: Corps étranger (balle) du poumon; extraction sous le contrôle de l'appareil Contremoulins. Archives d'électricité médicale 9:758, 1901

58. Loison M: Plaie pénétrante du rachis par projectile de petit calibre. Archives d'électricité médicale 9:757-758, 1901

59. Ludmerer KM: Time to Heal. Oxford: Oxford University Press, pp 21-25

60. Lunsford LD: Lars Leksell. Notes at the side of a raconteur. Stereo Func Neurosurgery 67:153-168, 1996-1997

61. Marey JE: Extraction des projectiles contenus dans le crâne 
et dont le siège précis a été déterminé par la méthode de MM. Rémy et Contremoulins. Bulletin de l'Académie de Médecine 37:478-481, 1897

62. Marey JE: Recherche des projectiles dans le cerveau. Gazette des Hôpitaux 70:1312, 1897

63. Marsault C: L'industrie de l'imagerie, in Merran S (ed): Cent ans d'imagerie médicale. Histoire et perspective d'aveni. Paris: Société Française de Radiologie et Imagerie Médicale, 1995, pp 154-158

64. Miller ER: Foreign body localization by X-ray. Cal West Med 57:349-351, 1942

65. Moreau JF: How does France save its radiological historical memory in the early XXIst century? Presented at the 1st ISHRAD Symposium, London, November 11, 2011. (http:// rmhserver2.netestate.de/ishrad/media/raw/History__Rad France_ISHRAD_2011.pdf) [Accessed November 30, 2016]

66. Moreau JF: Premier cinquantenaire de la radiologie à l'hôpital Necker: 1896-1946. La Lettre de l'Adamap 8:7-14, 2008

67. Mornet P: Gaston Contremoulins: (1869-1950) Pionnier visionnaire de la radiologie. Paris: AIHP, 2013

68. Mornet P: Gaston Contremoulins: un pionnier méconnu de la radioprotection. Radioprotection 46:109-124, 2011

69. Mould RF: A Century of X-Rays and Radioactivity in Medicine. Bristol: Institute of Physics Publishing, 1993

70. Ombredanne L, Ledoux-Lebard R: Localisation and Extraction of Projectiles. London: University of London Press, 1918

71. Pallardy G: La radiologie est entree avant l'electricite dans les hopitaux de Paris. Hist Sci Med 33:333-342, 1999

72. Pallardy G, Pallardy MJ, Wackenheim A: Histoire illustrée de la radiologie. Paris: R. DaCosta, 1989

73. Partridge WO: Technique of Sculpture. Boston: Ginn and Company, 1895, p 93

74. Pizon P: La radiologie en France (1896-1904). Paris: L'Expansion Scientifique Française, 1970

75. Plantureux S: Edmond Lebel: Le Concours du Prix de Rome. (http://www.photoceros.com/29-05-2006-edmondlebel-le-concours-de-rome/) [Accessed November 30, 2016]

76. Pool EH, Lee BJ, Dineed PA: Surgery of soft parts, bones and joints, at a front hospital. Surg Gynecol Obstet 27:289-311, 1918

77. Rahman M, Murad GJA, Mocco J: Early history of the stereotactic apparatus in neurosurgery. Neurosurg Focus 27(3):E12, 2009

78. Reid EK, Black LF: Foreign body localization in military roentgenology. Radiology 31:567-583, 1938

79. Rémy $\mathrm{C}$, Contremoulins G: Appareil destiné à déterminer d'une manière précise, au moyen des rayons $\mathrm{X}$, la position des projectiles dans le crâne. C R Acad Sci 125:831-836, 1897

80. Rémy C, Contremoulins G: De la radiophotographie des parties molles de l'homme et des animaux. C R Acad Sci 124:229-230, 1897

81. Rémy C, Contremoulins G: Emploi des rayons X pour les recherches anatomique: angiologie, développent, ossification, évolution des dents. C R Acad Sci 123:711, 1896

82. Rémy C, Contremoulins G: Le chercheur de projectiles. L'Illustration 55:423, 1897

83. Rémy C, Contremoulins G: Sur un nouveau perfectionnement des applications chirurgicales des rayons X. Bulletin de l'Académie de Médecine 37:354-358, 1897

84. Reynier PA: Plaie pénétrante du crâne par balle de revolver. Le Bull Medical 14:1263, 1900

85. Riechert T: Stereotactic Brain Operations: Methods, Clinical Aspects. Bern: Huber, 1980
86. Riesz PB: The life of Wilhelm Conrad Roentgen. AJR Am J Roentgenol 165:1533-1537, 1995

87. Routier AE: Nouvel appareil de M. Contremoulins pour la localisation radiologique des corps étrangers de la tête. Bulletin de L'Académie de Médecine 80:561-570, 1916

88. Scientific American: New system for locating bullets. Scientific American Suppl 44:18327-18328, 1897

89. Serletis D, Pait TG: Early craniometric tools as a predecessor to neurosurgical stereotaxis. J Neurosurg 124:18671874,2016

90. Shearer JS: Localization of foreign bodies: the standard methods approved by the surgeon general's office, U.S. Army. AJR Am J Roentgenol 5:229-247, 1918

91. Silverman ME: Etienne-Jules Marey: 19th century cardiovascular physiologist and inventor of cinematography. Clin Cardiol 19:339-341, 1996

92. Spiegel EA, Wycis HT, Marks M, Lee AJ: Stereotaxic apparatus for operations on the human brain. Science 106:349-350, 1947

93. Talairach J, David M, Tournoux P: L'Exploration chirurgicale stéréotaxique du lobe temporal dans l'epilepsie temporale. Paris: Masson, 1958

94. Thomas AMK, Banerjee AK: The History of Radiology. Oxford: Oxford University Press, 2013

95. Tillaux M: Décès de M. Marey. Bull de L’Académie de Médecine 51:426-430, 1904

96. Tuffier T: Plaies pénétrantes du crâne par armes à feu (utilité de la radiographie). Arch d'Electricité Médicale 9:249-250, 1901

97. United States Army Division of Roentgenology: United States Army X-Ray Manual. New York: Paul B. Hoeber, 1919

98. Van Tiggelen R: Radiology in a Trench Coat. Military Radiology on the Western Front During the Great War. Brussels: Academia Press, 2013

99. Ward HS: Practical Radiography. London: Dawbarn and Ward, 1896

100. Wegelius C: Concerning the differences between radiological and anatomical measurements. Acta Radiol 19:185204, 1938

101. Weiner BK: The case of James A. Garfield: a historical perspective. Spine (Phila Pa 1976) 28:E183-E186, 2003

102. Willette J: The French Academy: Sculpture. Art History Unstuffed. (http://www .arthistoryunstuffed.com/frenchacademy-sculpture/) [Accessed November 30, 2016]

\section{Disclosures}

The authors report no conflict of interest.

\section{Supplemental Information \\ Previous Presentations}

Portions of this work were presented as an oral presentation and abstract at the AANS meeting in Washington, D.C., in May 2015.

\section{Author Contributions}

Conception and design: Giller. Acquisition of data: all authors. Analysis and interpretation of data: Mornet, Moreau. Drafting the article: Giller. Critically revising the article: Giller, Moreau. Reviewed submitted version of manuscript: all authors. Administrative/technical/material support: Mornet.

\section{Correspondence}

Cole A. Giller, Neurosurgery Department, Augusta University, 1120 15th St., Augusta, GA 30912. mail: cgiller@augusta.edu. 